\title{
PENGARUH BRAINSTORMING DAN FRAUD RISK TERHADAP DETEKSI POTENSI KECURANGAN OLEH AUDITOR
}

\author{
Dien Auwaliah Latuconsina ${ }^{1}$, Syamsuri Rahim ${ }^{2}$ \\ Universitas Muslim Indonesia \\ Email : auwaliahl@gmail.com, syamsurirahim@umi.ac.id
}

\begin{abstract}
Abstrak
Penelitian ini bertujuan untuk menganalisis pengaruh brainstorming dan fraud risk terhadap deteksi potensi kecurangan oleh auditor. Hipotesis penelitian ini adalah brainstorming dan fraud risk berpengaruh signifikan terhadap deteksi potensi kecurangan oleh auditor. Data yang digunakan dalam penelitian ini adalah data primer dalam bentuk penilaian responden tentang brainstorming, fraud risk dan deteksi potensi kecurangan oleh auditor. Penelitian ini dilakukan di Badan Pengawasan Keuangan dan Pembangunan (BPKP) Provinsi Sulawesi Selatan dengan membagikan kuesioner/lembar pernyataan kepada 57 sampel auditor akan tetapi hanya 34 kuesioner yang dapat di olah. Metode analisis data menggunakan uji determinasi, uji F, analisis regresi linear berganda, dan uji t. Hasil penelitian menemukan bahwa brainstorming dan fraud risk berpengaruh signifikan terhadap deteksi potensi kecurangan oleh auditor BPKP Provinsi Sulawesi Selatan baik secara parsial maupun simultan.
\end{abstract}

Kata kunci : Brainstorming, Fraud Risk, Deteksi Kecurangan

\begin{abstract}
The aim of this research is to analyse the influence of brainstorming and fraud risk on detection of fraudulent potential by auditors. The hypotheses are about brainstorming and fraud risk has a significant impact on detection of fraudulent potential by auditors. The data required in this research is primary data in the form of respondent's assessment of brainstorming, fraud risk and detection of fraudulent potential by auditors. This research was carried out on Badan Pengawasan Keuangan dan Pembangunan (BPKP) of South Sulawesi Province by distributing questionnaires to 57 auditors as the respondent however only 34 questionnaires can be processed. Data analysis techniques used by determination test, $F$ test, Multiple Linear Regression test, and $t$ test. The results of the data analysis showed that the brainstorming and fraud risk have a significant influence on detection of fraudulent potential by auditors BPKP South Sulawesi Province either partially or simultaneously
\end{abstract}

Keywords : Brainstorming, Fraud Risk, Fraudulent Detection

\section{PENDAHULUAN}

Setiap tindakan manusia berpeluang untuk melakukan kesalahan. Kesalahan yang tidak sengaja disebut keliru atau khilaf sedangkan melakukan kesalahan yang sengaja merupakan ketidakjujuran atau tindakan kecurangan. Tindakan kecurangan biasanya disebut dengan istilah fraud. Fraud sangat berbahaya dan merugikan banyak pihak sehingga termasuk salah satu tindakan kejahatan yang berhubungan dengan penyelewengan. Biasanya dalam pengelolaan keuangan fenomena kecurangan (fraud) yang digambarkan sebagai white collar crime sering terjadi. Seharusnya kecurangan tersebut mampu terdeteksi dalam ranah organisasi atau perusahaan.

Penelitian Aghghaleh et. al. (2014) pada beberapa perusahaan di Malaysia menemukan bahwa kemungkinan adanya peristiwa kecurangan lebih banyak terjadi, salah satunya pada transaksi penjualan di accounts receivables. Ini sama halnya dengan Indonesia yang mana kasus kecurangan berpotensi menimbulkan kerugian besar bagi negara. Tingkat kecurangan suatu negara ditunjukkan oleh tingkat korupsi negara 


\section{AkMen \\ Volume 18 Nomor 2 Agustus 2021 \\ Hal. $219-233$ \\ e-ISSN : 2621-4377 \& p-ISSN : 1829-8524 \\ Hbmepage: https//e-jurnal.nobel.acid/indexphp/akmen}

tersebut (Shleifer \& Vishny, 1993). Tranparency International (TI) merilis Corruption Perceptions Index (CPI) yang mana Indonesia menempati peringkat ke 88 dari 168 negara dengan skor 36 pada tahun 2015. Ini menunjukkan tingginya angka korupsi di sektor publik Indonesia (Butar, 2017). Terbukti bahwa dari paling bawah tingkatan level daerah Indonesia Corruption Watch (ICW) telah mengawasi tindakan korupsi yang terjadi di desa. Hasil pemantauan ICW pada tahun 2015 - 2017 bahwa kasus tindak pidana korupsi di desa semakin meningkat. Kasus korupsi mencapai 17 kasus pada tahun 2015 dan melonjak menjadi 41 kasus pada tahun 2016. Peningkatan yang sangat signifikan terjadi di tahun 2017 dengan 96 kasus. Sehingga seluruh kasus korupsi yang teridentifikasi berjumlah 154 kasus (Alfaruqi \& Kristianti, 2019).

Auditor memiliki peran yang besar dalam mencegah dan mendeteksi kecurangan karena keberadaannya yang melekat dalam sebuah organisasi (Rahim et al., 2020; Su'un et al., 2020; Lannai \& Muslim, 2021). Upaya ini dianggap efektif dan efisien karena lebih mudah diterapkan daripada tindakan yang bersifat reaktif seperti audit forensik untuk kecurangan (Suryanto et al., 2017). Semakin tingginya kemampuan auditor dalam mendeteksi kecurangan mendukung semakin tingginya transparansi dan independensi auditor (Amran et al., 2021). Terlacaknya misstatement akan membuka jalan mengenai salah saji laporan keuangan yang merugikan suatu entitas. Setelah penemuan bukti akan kesalahan, komunikasi kepada pihak yang bersangkutan membantu untuk mengevaluasi kesalahan (Suryoratri, 2012).

Suryoratri (2012) bahwasanya pada SAS No. 82 Consideration of Fraud in a Financial Statement Audit AU seksi 316 menyatakan bahwa auditor dapat meningkatkan kemungkinan penemuan adanya kecurangan dengan bantuan pertukaran pendapat dalam tim audit atau disebut brainstorming. Pertukaran pendapat ini berupa diskusi yang membicarakan mengenai kecurigaan masing-masing anggota tim audit mengenai kemungkinan adanya kesalahan. Berdasarkan faktor risiko kecurangan (fraud risk factors) dalam penelitian Brazel et. al. (2010) yang dikenal dengan nama segitiga kecurangan (triangle fraud) mendorong fraudster melakukan fraud antara lain tekanan (incentives), kesempatan (opportunies), dan rasionalisasi (rasionalizations) bertujuan membuktikan bahwa fraudster melakukan kecurangan dengan adanya alasan dari faktorfaktor tersebut.

Beberapa penelitian terdahulu menghasilkan kesepakatan bahwa brainstorming membantu tim audit menentukan risiko audit lebih efisien dibandingkan penaksiran individual. Seperti penelitian Chen et. al. (2018) dalam temuan mereka menyarankan dan menerapkan brainstorming untuk meningkatkan kinerja auditor dalam menemukan penipuan/tindakan kecurangan. Mohd Nassir et. al. (2016) menemukan ketidakmampuan auditor pemerintah untuk mendeteksi salah saji, terutama pada risiko kecurangan yang dapat mengekspos auditor terhadap tuntutan hukum yang akibatnya menyebabkan reputasi buruk kepada publik. Penelitian ini juga menunjukkan bahwa brainstorming dan keahlian auditor berdampak pada kinerja auditor pemerintah terhadap penilaian risiko penipuan. Temuan penelitian ini memberikan wawasan tentang pentingnya brainstorming untuk auditor pemerintah dengan beragam keahlian.

Akan tetapi penelitian eksperimen Prasetyo (2017) tentang kualitas keputusan dan peringkat kemungkinan kecurangan dalam penilaian risiko kecurangan oleh kelompok atau individu dengan dan tanpa bantuan keputusan, menemukan bahwa ternyata baik kelompok brainstorming dan bantuan keputusan tidak berpengaruh signifikan terhadap penilaian risiko kecurangan. Sehingga tujuan dari penelitian ini adalah untuk 


\section{AkMen \\ Volume 18 Nomor 2 Agustus 2021 \\ Hal. 219 - 233 \\ e-ISSN : 2621-4377 \& p-ISSN : 1829-8524 \\ Homepage: https//e-jurnal.nobel.acid/indexphp/akmen}

menganalisis apakah brainstroming dan fraud risk mempengaruhi adanya deteksi potensi kecurangan oleh auditor. Mengingat pentingnya peran para auditor di Badan Pengawasan Keuangan dan Pembangunan dalam kelangsungan pemerintahan maka objek penelitian dilakukan di BPKP Provinsi Sulawesi Selatan.

Salah satu teori yang menjelaskan tentang motivasi seseorang melakukan fraud adalah Fraud Triangle Theory. Fraud triangle terdiri atas tiga elemen yaitu opportunity, pressure, dan rationalization. Tiga elemen kecurangan yang diringkas oleh Cressey dalam Ratmono (2017) biasanya disajikan dalam diagram gambar yang ditunjukkan di bawah ini.

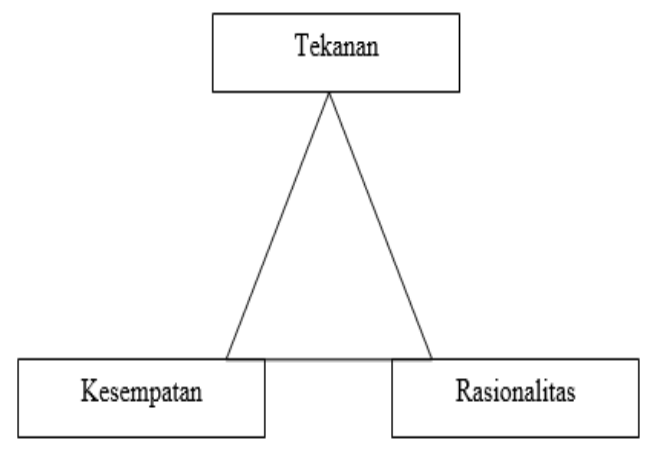

\section{Gambar 1. Fraud Triangle}

Ada 3 hal yang mendorong terjadinya sebuah upaya fraud, yaitu pressure (dorongan), opportunity (peluang), dan rationalization (rasionalisasi), seperti berikut ini: (1) pressure adalah dorongan yang menyebabkan seseorang melakukan fraud. Pada umumnya, yang mendorong terjadinya fraud adalah kebutuhan atau masalah finansial. Akan tetapi, fraud juga banyak terjadi dikarenakan suatu individu terdorong oleh keserakahan; (2) opportunity adalah kesempatan/ peluang yang memungkinkan fraud terjadi. Dalam hal ini fraud biasanya disebabkan karena internal control suatu organisasi yang lemah dan juga kurang nya pengawasan sehingga terjadi penyalahgunaan wewenang; (3) rationalization menjadi elemen yang penting karena dalam terjadinya fraud, dimana para pelaku kecurangan memberi pembenaran atas tindakan yang dilakukan. Pengungkapan fraud dapat diidentifikasi dengan melakukan investigasi dimana auditor melakukan proses mencari, menemukan, dan mengumpulkan bukti secara sistematis. Pengungkapan fraud yang dilakukan oleh seorang auditor diharapkan dapat mengurangi tingkat kecurangan yang tinggi sehingga mengurangi kerugian bagi pihak-pihak yang berkepentingan. Pengungkapan fraud yang dilakukan oleh auditor juga diharapkan dapat menjaga kepercayaan publik akan independensi, profesionalitas sehingga kinerja auditor tetap terjaga. Auditor harus memiliki kemampuan untuk mengungkapkan fraud yang sebelumnya telah terdeteksi oleh berbagai pihak. Upaya pengungkapan fraud perlu ditingkatkan serta diintensifkan dengan tetap menjunjung tinggi kepercayaan masyarakat (Dewi \& Ramantha, 2016).

Pada tahun 1975 teori ini pertama kali dikemukakan oleh Charles Berger dan Richard Calabrese (Berger et al., 2018). Teori ini membahas perihal sebuah proses komunikasi yang terjadi pada dua individu yang sebelumnya tidak saling mengenal hingga menjadi saling mengenal sehingga dapat mengurangi ketidakpastian dalam komunikasi. Sehingga kemudian individu tersebut dapat memutuskan untuk keinginannya untuk melanjutkan atau menghentikan komunikasi. Teori ini juga 


\section{AkMen \\ Homepage: https//e-jurnal.nobel.acid/index.php/akmen}

berhubungan dengan cara-cara yang dilakukan oleh seorang individu untuk mengumpulkan informasi tentang orang lain. Teori ini berkaitan dengan cara-cara individu memantau lingkungan sosial dan memiliki pengetahuan lebih banyak tentang pribadi individu tersebut maupun orang lain.

Charles R. Berger (1988) dalam Alkotdriyah (2020), mengatakan bahwa perolehan, pemrosesan, retensi, dan pengambilan informasi sangat penting untuk pertumbuhan, pemeliharaan, dan penurunan hubungan pribadi dan sosial. Hubungan bisa dipandang sebagai sistem pertukaran informasi yang harus mengurangi ketidakpastian dalam bertahan hidup. Mark V. Redmond (2015), menjelaskan teori ini menyatakan terdapat dua tipe dari ketidakpastian dalam perjumpaan pertama yaitu: (1) cognitive uncertainty merupakan tingkatan ketidakpastian yang diasosiasikan dengan keyakinan dan sikap; (2) behavioral uncertainty, dilain pihak berkenaan dengan luasnya perilaku yang dapat diprediksikan dalam situasi yang diberikan. Selanjutnya Berger dan Calabrese (1975) berpendapat bahwa uncertainty reduction memiliki proses yang proaktif dan retroaktif. Uncertainty reduction yang proaktif yaitu ketika seseorang berpikir tentang pilihan komunikasi sebelum benar-benar terikat dengan orang lain. Uncertainty reduction yang retroaktif terdiri dari usaha-usaha untuk menerangkan perilaku setelah pertemuan itu sendiri.

Pada tahun 1953 metode brainstorming diperkenalkan oleh Alex F. Osborn pada saat mencari solusi dari permasalahan perusahaannya dengan cara berdiskusi secara kreatif dan bebas mengungkapkan pendapat dengan setiap karyawannya (Osborn, 1953). Kemudian metode ini dianggap sebagai strategi pemecahan masalah dalam setiap diskusi kelompok individu. Seiring perkembangannya, Osborn menetapkan aturan dasar metode brainstorming ini bahwa pendapat yang ada dikumpulkan tanpa memperdulikan pendapat tersebut muncul dari siapa yang berpendapat. Adapun empat aturan dasar dalam brainstorming oleh Osborn (Mardiyati, 2001) sebagai berikut: (1) tidak memberikan kritik; (2) kebebasan dalam memberikan gagasan; (3) memberikan banyak gagasan; (4) gabungan dan perbaikan ide. Dalam artikel CPE oleh Brown (2015) yang berjudul "Conducting Effective Fraud Brainstorming Sessions: Best Practice Tips and Available Resources for Your Audit Teams", dijelaskan bahwa langkah-langkah metode fraud brainstorming seperti memilih tim, menentukan pendekatan, menyiapkan perkumpulan, melakukan perkumpulan, tindak lanjut kemudian dokumentasi. Terkait langkah dalam menentukan pendekatan atau metode brainstorming, maka terdapat dalam artikel tersebut dijelaskan tentang beberapa metode brainstorming.

Metode yang sering digunakan dalam sebuah fraud brainstorming adalah dilakukan secara tatap muka. Dalam pendekatan ini, pemimpin tim akan memulai diskusi dengan memperkenalkan topik dan menekankan setiap anggota untuk menyampaikan ide - ide sesuai topik yang sudah dijelaskan. Anggota diberikan kebebasan untuk memberikan gagasan atau ide.

Strategic Reasoning, Metode ini mendorong auditor untuk berpikir bagaimana kecurangan bisa terjadi dan akun mana yang paling rentan (dalam sektor privat). Teknik ini digunakan untuk mengidentifikasi bermacam bentuk kecurangan dibandingkan hanya meningkatkan ukuran sampel prosedur audit.

Computer-Mediated, Lingkungan audit yang berteknologi komputerisasi saat ini telah banyak mengubah cara kerja audit. Sesi fraud brainstorming juga dapat ditingkatkan dengan memasukkan sistem pertemuan elektronik atau sistem pendukung grup lainnya. Mengingat sesi brainstorming yang dimediasi komputer juga digunakan 


\section{AkMen \\ Volume 18 Nomor 2 Agustus 2021 \\ Hal. $219-233$ \\ e-ISSN : 2621-4377 \& p-ISSN : 1829-8524 \\ Hbmepage: https//e-jurnal.nobel.acid/index.php/akmen}

untuk mempersingkat waktu rapat, pendekatan ini dapat menjadi alternatif yang bermanfaat untuk tim audit.

Mind - Mapping, Metode ini menguraikan proses untuk menggunakan pemetaan pikiran ketika melakukan sesi fraud brainstorming. Pemetaan pikiran memungkinkan tim audit untuk memvisualisasikan dan mengaturnya secara real time saat pembahasan. Sebagian besar penelitian brainstorming pada penipuan berkonsentrasi di pertemuan tim brainstorming itu sendiri (Trotman et al., 2015). Menurut Chen et. al. (2018) salah satu masukan penting untuk pertemuan brainstorming tim adalah tahap pembuatan ide auditor individu dalam persiapan untuk pertemuan ini. Dalam literatur audit ini disebut sebagai brainstorming individu (Hoffman \& Zimbelman, 2009). Adapun dalam penelitan Brazel et. al. (2010) menjelaskan penggunaan auditor tentang brainstorming dalam pertimbangan penipuan sebagai berikut:

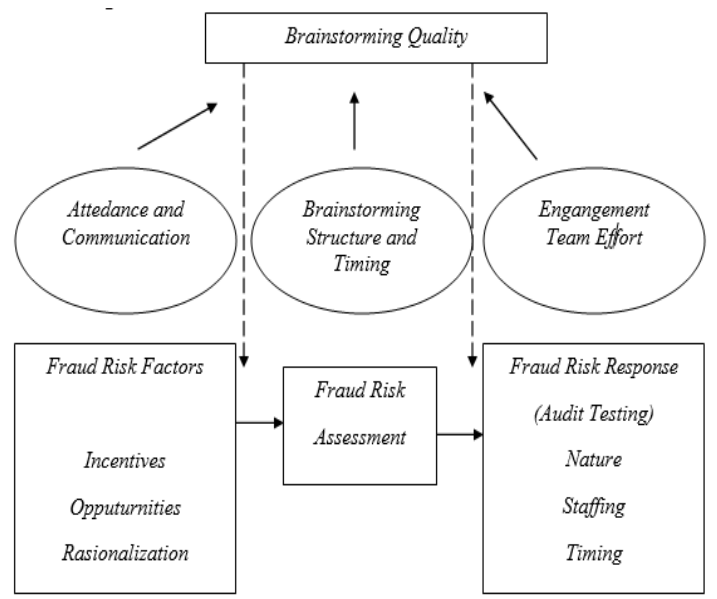

Gambar 2. Brainstroming Quality

Istilah fraud menurut SPA (Standar Perikatan Audit) 240 yang diterbitkan Institut Akuntan Publik Indonesia (IAPI) (2012) bahwa fraud (kecurangan) adalah suatu tindakan yang disengaja oleh satu individu atau lebih dalam manajemen, pihak yang bertanggung jawab atas tata kelola, karyawan, atau pihak ketiga, yang melibatkan penggunaan tipu muslihat untuk memperoleh suatu keuntungan secara tidak adil atau melanggar hukum. Menurut Oxford Learners Dictionaries (2005) fraud is the crime of cheating somebody in order to get money or goods illegally or a person who pretends to have qualities, abilities, etc. that they do not really have in order to cheat other people. Sedangkan Kamus Besar Bahasa Indonesia (KBBI) dalam Daring (KBBI, 2012), curang (fraud) adalah perihal curang, ketidakjujuran, keculasan. Association of Certified Fraud Examiners (ACFE) mendefenisikan fraud is the use of one's occupation for personal enrichment through the deliberate misuse or misapplication of the employing organization's resources or assets (ACFE, 2012). Jadi, fraud adalah menggunakan pekerjaan seseorang untuk pengayaan pribadi melalui penyalahgunaan yang disengaja dari sumber daya maupun aset di sebuah organisasi (tempat bekerja). Adapun menurut Tuanakotta (2015) fraud adalah An intentional act by one or more individuals among management, those charged with governnance, employees, or third parties, involving the use of deception to obtain anunjust or illegal advantage. Pernyataan tersebut menjelaskan bahwa fraud ialah setiap perbuatan yang disengaja oleh satu orang atau 
lebih dalam tim manajemen, pengawasan, karyawan, atau pihak ketiga dengan cara menipu untuk memperoleh keuntungan yang illegal.

Resiko fraud adalah jenis resiko yang umum dihadapi oleh setiap perusahaan. Fraud berdampak buruk mulai dari kerugian finansial hingga reputasi yang rusak. Resiko ini tidak boleh dianggap sebelah mata karena dapat membuat perusahaan berada dalam kondisi yang sangat rentan (Intergrity Indonesia, 2017). Menurut Kementerian Keuangan Learning Center (2019) bahwa adanya potensi terjadinya risiko kecurangan (fraud) yang dilakukan lembaga maupun individu sebagai pejabat di dalam organisasi pemerintahan adalah merupakan hal yang sangat mungkin terjadi dan apabila terjadi akan sangat merugikan keuangan dan reputasi organisasi tersebut.

Tingkat kemampuan auditor untuk mendeteksi kecurangan berbeda karena dipengaruhi oleh faktor internal dan faktor eksternal (Muslim et al., 2019). Namun, faktor yang lebih dominan mempengaruhi adalah faktor internal, yaitu faktor yang berasal dari dalam auditor, seperti professional skeptisisme dan pengalaman auditor, oleh karena itu kecurangan yang tidak dapat dideteksi di proses audit merupakan bentuk gambaran kelemahan kemampuan auditor dalam mendeteksi kecurangan dan menggambarkan peningkatan jumlah mode yang dilakukan oleh penipu untuk menyembunyikan penipuan. Ini akan berdampak pada munculnya kerugian besar bagi perusahaan secara procedural cacat dalam proses penyajian laporan keuangan (Jefri \& Mediaty, 2014)

Kemampuan auditor untuk mendeteksi kecurangan sangat tergantung pada tingkat pengalaman dan pengetahuan yang dimilikinya (Minaryanti \& Ridwan, 2015). Tanggung jawab yang di pegang oleh auditor untuk mendeteksi penipuan yang terjadi akan menimbulkan peringatan dan sikap kritis terhadap pengumpulan dan evaluasi bukti yang disajikan oleh manajemen perusahaan. Tanggung jawab auditor untuk mendeteksi kecurangan yang terjadi akan menimbulkan sikap hati-hati dan kritis terhadap pengumpulan dan evaluasi bukti yang disajikan oleh manajemen perusahaan (Rahim et al., 2019). Menurut Kumaat (2011) mendeteksi kecurangan adalah upaya untuk mendapatkan indikasi awal yang cukup mengenai tindakan kecurangan, sekaligus mempersempit ruang gerak para pelaku kecurangan. Dalam melakukan pendeteksian yang bertujuan untuk meminimalisir kecurangan, keterampilan dan kompetensi merupakan sesuatu yang harus dikuasai dan dimiliki oleh auditor. Kompetensi auditor berpengaruh secara signifikan dalam mendeteksi kecurangan laporan keuangan.

\section{METODE PENELITIAN}

Analisis data dilakukan dengan menggunakan bantuan program computer Statistical Product and Service Solutions (SPSS). Metode analisis yang digunakan dalam penelitian ini adalah Analisis Statistik Dekskirptif; (2) Uji Instrumen Penelitian (Uji Validitas \& Uji Reliabilitas); (3) Uji Asumsi Klasik (Uji Normalitas, Uji Multikolinieritas, \& Uji Heteroskedastisitas); (4) Uji Hipotesis ( koefisien determinan $\left(\mathrm{R}^{2}\right)$, Uji F, Analisis Regresi Berganda \& Uji parsial (Uji t)

\section{HASIL DAN PEMBAHASAN \\ Hasil}

Uji validitas dilakukan untuk mengetahui apakah instrumen penelitian yang digunakan adalah valid dan dapat digunakan sebagai alat ukur penelitian. Hasil uji 
validitas pada tabel 1 menunjukkan bahwa semua item pertanyaan dalam dalam kuesioner memiliki nilai Corrected Item - Total > 0,286 sehingga dinyatakan valid

Tabel 1. Hasil Uji Validitas

\begin{tabular}{|c|c|c|c|}
\hline Variabel & Pertanyaan & $\begin{array}{c}\text { r-hitung > r- } \\
\text { tabel }\end{array}$ & Keterangan \\
\hline \multirow[t]{4}{*}{ Brainstorming } & $\mathrm{X} 11$ & $0,286^{0,798}$ & Valid \\
\hline & $\mathrm{X} 12$ & $0,2866^{0,857}$ & Valid \\
\hline & $\mathrm{X} 13$ & $0,286^{0,838}$ & Valid \\
\hline & $\mathrm{X} 14$ & $0,286{ }^{0,857}$ & Valid \\
\hline \multirow[t]{4}{*}{ Fraud Risk (X2) } & $\mathrm{X} 41$ & $0,2866^{0,829}$ & Valid \\
\hline & $\mathrm{X} 42$ & $0,286^{0,672}$ & Valid \\
\hline & $\mathrm{X} 43$ & 0,286 & Valid \\
\hline & X44 & $0,286{ }^{0,657}$ & Valid \\
\hline \multirow{5}{*}{$\begin{array}{l}\text { Deteksi Potensi } \\
\text { Kecurangan (Y) }\end{array}$} & Y1 & $0,286 \quad 0,922$ & Valid \\
\hline & Y2 & $0,2866^{0,789}$ & Valid \\
\hline & Y3 & $0,286{ }^{0,808}$ & Valid \\
\hline & Y4 & $0,286 \quad 0,752$ & Valid \\
\hline & Y5 & $0,286{ }^{0,719}$ & Valid \\
\hline
\end{tabular}

Sumber: Output SPSS, 2020

Hasil pengujian reliabilitas, tabel 2 menunjukkan bahwa semua variabel yang dijadikan instrumen dalam penelitian adalah reliabel dan dapat digunakan sebagai alat pengumpulan data. Sehingga berdasarkan hasil uji reliabilitas diatas, menunjukkan bahwa instrument memiliki tingkat reliabilitas yang tinggi, hal ini dibuktikan dengan nilai koefisien alpha > 0,60, jadi hasil ukur yang akan didapatkan dapat dipercaya.

Tabel 2 . Uji Reliabilitas

\begin{tabular}{|c|c|c|}
\hline Variabel & Koefisien Alpha & Keterangan \\
\hline Brainstorming & 0,856 & Baik \\
\hline Fraud Risk & 0,628 & Cukup \\
\hline Deteksi Potensi Kecurangan & 0,855 & Baik \\
\hline
\end{tabular}


Uji normalitas dilakukan untuk melihat apakah dalam model regresi variabel terikat dan variabel bebas keduanya mempunyai distribusi normal atau tidak. Model regresi yang baik adalah model regresi yang berdistribusi normal. Cara mendeteksi normalitas dilakukan dengan melihat grafik histogram.

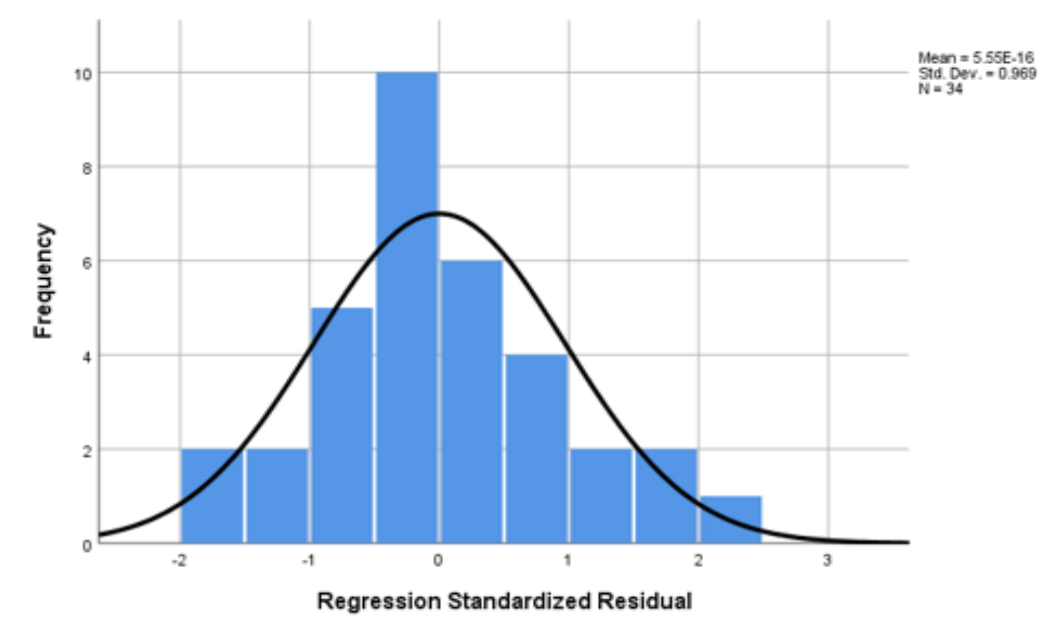

Gambar 3. Grafik Histogram

Berdasarkan grafik histogram pada gambar 3, dapat disimpulkan bahwa grafik histogram memberikan pola distribusi yang mendekati normal, hal ini dibuktikan dengan melihat bahwa grafik membentuk simetris dan mengikuti garis diagonal. Akan tetapi grafik histogram ini hasilnya tidak terlalu akurat apalagi ketika jumlah sampel yang digunakan kecil.

Metode yang handal adalah dengan melihat normal probability plot. Pada grafik normal plot terlihat titik-titik menyebar disekitar garis diagonal serta penyebarannya mengikuti arah garis diagonal.

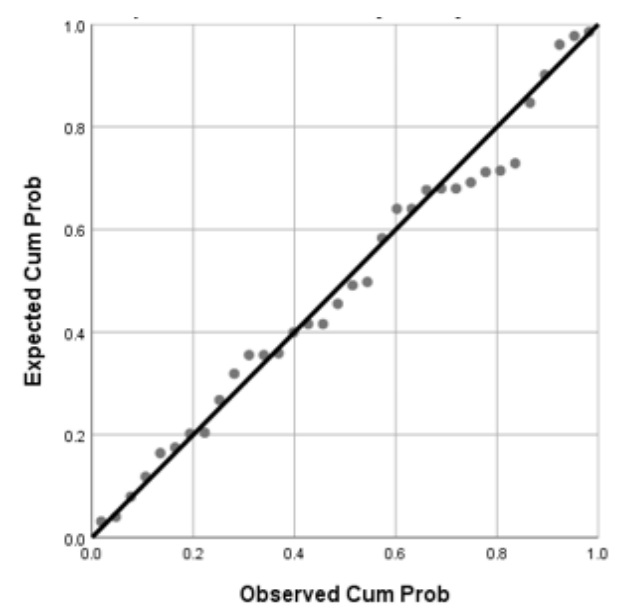

Gambar 4. Normal Probability Plot 
Berdasarkan grafik normal probability plot, dapat dilihat bahwa titik menyebar disekitar garis diagonal dan penyebarannya mengikuti garis diagonal, sehingga dapat dikatakan bahwa pola distribusinya normal. Melihat kedua grafik diatas, dapat disimpulkan bahwa model regresi dalam penelitian ini dapat digunakan karena memenuhi asumsi normalitas.

Uji heteroskedastisitas dilakukan untuk menunjukkan bahwa variansi variabel tidak sama untuk semua pengamatan. Jika variansi dari residual satu pengamatan ke pengamatan yang lain tetap, maka disebut homoskedastisitas. Model regresi yang baik adalah yang homoskedastisitas atau tidak terjadi heteroskedastisitas karena data cross section memiliki data yang mewakili berbagai ukuran (kecil, sedang, dan besar). Untuk mendeteksi adanya Heteroskedastisitas, metode yang digunakan adalah metode chart (diagram Scatterplot). Jika: Jika ada pola tertentu terdaftar titik-titik, yang ada membentuk suatu pola tertentu yang beraturan (bergelombang, melebar, kemudian menyempit), maka terjadi Heteroskedastisitas begitu juga sebaliknya.

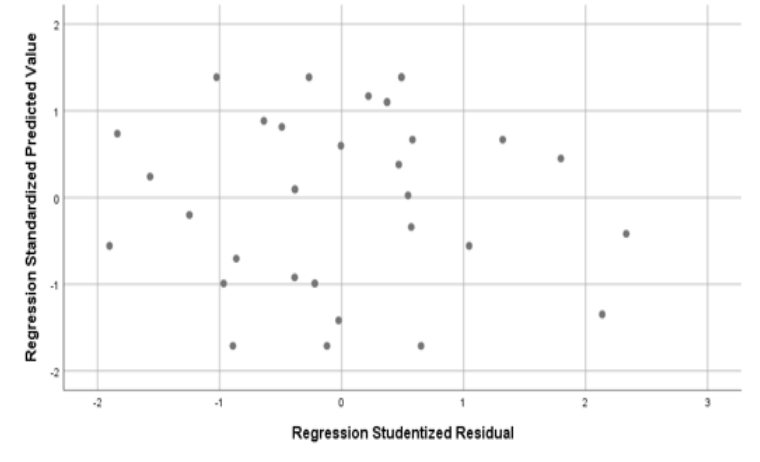

\section{Gambar 5. Diagram Scatterplot}

Berdasarkan diagram diatas, maka dapat dilihat bahwa data tersebar secara acak dan tidak membentuk suatu pola tertentu, hal ini menunjukkan bahwa tidak terdapat heteroskedastisitas. Dengan demikian dapat disimpulkan bahwa terjadinya perbedaan varians dari residual dari suatu pengamatan ke pengamatan yang lain.

Tabel 3. Uji Multikolinearitas

\begin{tabular}{|c|c|c|}
\hline Variabel & VIF & Keterangan \\
\hline Brainstorming & 1,370 & Tidak Multikolinearitas \\
\hline Fraud Risk & 1,370 & Tidak Multikolinearitas \\
\hline
\end{tabular}

Selanjutnya dilakukan uji Multikolinearitas bertujuan menguji adanya korelasi antara variabel bebas (independent) pada model regresi. Pada model regresi yang baik seharusnya tidak terjadi korelasi diantara variabel. Untuk menguji ada atau tidaknya multikolinearitas dalam model regresi dapat dilihat dari nilai tolerance dan lawannya, yaitu dengan melihat variance inflation factor (VIF). Nilai cut-off yang umum dipakai adalah nilai tolerance 0,01 . Salah satu cara untuk menguji adanya multikoloniearitas dapat dilihat dari Variance Inflation Factor (VIF). Jika nilai VIF>10 maka terjadi multikolinearitas. Berdasarkan tabel 3, dapat disimpulkan bahwa model regresi untuk variabel independen yang diajukan oleh peneliti untuk diteliti bebas dari 


\section{AkMen \\ Volume 18 Nomor 2 Agustus 2021 \\ Hal. 219 - 233 \\ e-ISSN : 2621-4377 \& p-ISSN : 1829-8524 \\ Hbmepage: https//e-jurnal.nobel.acid/index.php/akmen}

multikolinearitas. Hal ini dapat dibuktikan dari nilai VIF dari masing-masing variabel independen $<10$, dan dapat digunakan untuk mengetahui pengaruh brainstorming dan fraud risk terhadap deteksi potensi kecurangan.

Analisis koefisien determinasi digunakan untuk mengetahui persentase besarnya pengaruh variabel independen terhadap variabel independen. Tabel 4 menunjukkan bahwa hasil uji koefisien deteminasi di atas, diketahui bahwa deteksi potensi kecurangan mampu dijelaskan oleh variabel brainstorming dan fraud risk sebesar $83,0 \%$. Sisanya $17,0 \%$ dari deteksi potensi kecurangan dijelaskan oleh variabel lain yang tidak disertakan dalam penelitian.

Tabel 4. Uji Determinasi

\begin{tabular}{|c|c|c|c|c|}
\hline Model & R & R Square & Adjusted R Square & $\begin{array}{c}\text { Std. Error of the } \\
\text { Estimate }\end{array}$ \\
\hline 1 & $.911 \mathrm{a}$ & .830 & .819 & .27692 \\
\hline
\end{tabular}

Tabel 5. Uji F

\begin{tabular}{|l|l|l|l|l|l|l|}
\hline \multicolumn{2}{|l|}{ Model } & Sum of Squares & df & Mean Square & F & Sig. \\
\hline \multirow{2}{*}{1} & Regression & 11.628 & 2 & 5.814 & 75.815 & $.000 \mathrm{~b}$ \\
\cline { 2 - 7 } & Residual & 2.377 & 31 & .077 & & \\
\cline { 2 - 7 } & Total & 14.005 & 33 & & & \\
\hline
\end{tabular}

Uji $\mathrm{F}$ digunakan untuk mengetahui pengaruh simultan dari semua variabel independet $(\mathrm{X})$ terhadap variabel dependen (Y). Pengujian dilakukan dengan taraf signifikansi 0,05. Jika Sig.>0,05 maka hipotesis yang diajukan ditolak. Sebaliknya Jika Sig.<0,05 maka hipotesis yang diajukan diterima. Berdasarkan hasil uji simultan yang telah dilakukan antara variabel brainstorming dan fraud risk terhadap deteksi potensi kecurangan diketahui bahwa nilai Sig. adalah sebesar 0,000. Nilai tersebut lebih kecil dari derajat kesalahan $(\alpha=0,05)(0,00<0,05)$. Dengan kata lain, variabel brainstorming dan fraud risk secara simultan memiliki pengaruh signifikan terhadap deteksi potensi kecurangan.

Uji regresi linear berganda dilakukan untuk mengetahui hubungan fungsional antara variabel bebas (independent) terhadap varaiabel terikat (dependent). Hasil uji regresi linear berganda dapat dilihat dari persamaan berikut. Penelitian ini menguji pengaruh brainstorming dan fraud risk terhadap deteksi potensi kecurangan.

Tabel 6. Hasil uji Hipotesis

\begin{tabular}{|c|c|c|c|c|c|c|c|}
\hline \multirow[b]{2}{*}{ Model } & \multicolumn{2}{|c|}{$\begin{array}{l}\text { Unstandardized } \\
\text { Coefficients }\end{array}$} & \multirow{2}{*}{$\begin{array}{l}\text { Standardized } \\
\text { Coefficients }\end{array}$} & \multirow[b]{2}{*}{$\mathbf{T}$} & \multirow[b]{2}{*}{ Sig. } & \multicolumn{2}{|c|}{$\begin{array}{l}\text { Collinearity } \\
\text { Statistics }\end{array}$} \\
\hline & B & $\begin{array}{l}\text { Std. } \\
\text { Error }\end{array}$ & & & & Tolerance & VIF \\
\hline \begin{tabular}{l|l} 
& (Constant)
\end{tabular} & -.912 & .422 & & -2.161 & .038 & & \\
\hline Brainstorming & .515 & .072 & .622 & 7.177 & .000 & .730 & 1.370 \\
\hline Fraud Risk & .680 & .141 & .417 & 4.817 & .000 & .730 & 1.370 \\
\hline
\end{tabular}


Berdasarkan tabel Coefficients hasil output SPSS sebagaimana tampilan tabel 6, maka diketahui persamaan regresi sebagai berikut:

$$
\mathrm{Y}=-0,912+0,515 \mathrm{X} 1+0,680 \mathrm{X} 2
$$

Dalam persamaan regresi linear berganda di atas dapat dijelaskan secara rinci:

Konstanta sebesar $-0,912$. Hal ini berarti jika tidak ada perubahan dari variabel brainstorming dan fraud risk, maka kemampuan deteksi potensi kecurangan akan menurun sebesar 0,912. Nilai koefisien regresi untuk brainstorming sebesar 0,515. Dalam penelitian ini dapat dinyatakan bahwa brainstorming berpengaruh positif terhadap deteksi potensi kecurangan. Setiap peningkatan brainstorming akan memberikan dampak pada meningkatnya deteksi potensi kecurangan sebesar 0,515. Nilai koefisien regresi untuk fraud risk sebesar 0,680. Dalam penelitian ini dapat dinyatakan bahwa fraud risk berpengaruh positif terhadap deteksi potensi kecurangan. Setiap peningkatan fraud risk akan memberikan dampak pada meningkatnya deteksi potensi kecurangan sebesar 0,680 .

Selanjutnya adalah pengujian secara parsial untuk mengetahui apakah variabel independet $(\mathrm{X})$ berpengaruh signifikan terhadap variabel dependen (Y). Pengujian dilakukan dengan taraf signifikansi 0,05. Jika Sig>0,05 maka hipotesis yang diajukan ditolak. Sebaliknya Jika Sig. < 0,05 maka hipotesis yang diajukan diterima.

Tabel 7 . Uji t

\begin{tabular}{|c|c|c|c|}
\hline Varibel & Sig. $<\boldsymbol{\alpha}$ & Keterangan & Hipotesis \\
\hline Brainstorming & $0,000<0,05$ & Signifikan & Diterima \\
\hline Fraud Risk & $0,000<0,05$ & Signifikan & Diterima \\
\hline
\end{tabular}

Berdasarkan hasil uji parsial diketahui bahwa brainstorming (X1) dan fraud risk (X2) masing - masing secara parsial memiliki pengaruh yang signifikan terhadap deteksi potensi kecurangan.

\section{Pembahasan}

\section{Pengaruh Brainstorming Terhadap Deteksi Potensi Kecurangan Oleh Auditor}

Brainstorming dalam penelitian ini didefinisikan sebagai bentuk dari pertukaran pendapat yang dilakukan oleh auditor. Brainstorming dalam penelitian ini diukur menggunakan tiga indikator yaitu: kualitas brainstorming, materi brainstorming, dan efektivitas brainstorming. Berdasarkan hasil penelitian diketahui bahwa brainstorming memiliki pengaruh positif terhadap deteksi potensi kecurangan oleh auditor. Hal ini berarti bahwa semakin sering auditor menerapkan brainstorming maka akan berdampak pada semakin baik auditor dalam mendeteksi potensi kecurangan. Hal ini sejalan dengan uncertainty reduction theory di mana brainstorming merupakan sesi yang digunakan para auditor untuk memitigasi ketidakpastian (uncertainty). Melalui brainstorming para auditor dapat mengidentifikasi bentuk-bentuk, factor-faktor terjadinya kecurangan dan pihak-pihak yang terlibat. Jika auditor menerapkan brainstorming dengan efektif maka ketidakpastian terhadap proses audit yang dilakukan kepada klien akan dapat diminimalisir. Sementara itu, berdasarkan uji parsial diketahui bahwa brainstorming memiliki pengaruh yang signifikan terhadap deteksi potensi kecurangan. Hal ini berarti bahwa brainstorming merupakan faktor penentu baik dan tidaknya kemampuan auditor dalam mendeteksi potensi kecurangan. Hasil penelitian ini menujukkan bahwa 


\section{AkMen \\ Volume 18 Nomor 2 Agustus 2021 \\ Hal. $219-233$ \\ e-ISSN : 2621-4377 \& p-ISSN : 1829-8524 \\ Hbmepage: https//e-jurnal.nobel.acid/indexphp/akmen}

pelaksanaan brainstorming yang dilakukan para auditor di lingkup BPKP Provinsi Sulawesi Selatan sangat berkualitas dengan materi yang baik dan efektif dalam pelaksanaannya. Hal inilah yang menyebabkan brainstorming memiliki kontribusi dalam meningkatkan kemampuan auditor dalam mendeteksi potensi kecurangan. Hasil penelitian ini sejalan dengan hasil penelitian sebelumnya dari Joseph, dkk (2010), Mohd. Nassir, dkk (2015), Mohd. Nassir, dkk (2016), Wei Chen, dkk (2018) dan Trie, dkk (2018) yang menemukan brainstorming berkontribusi dan berpengaruh signifikan terhadap deteksi potensi kecurangan.

\section{Pengaruh Fraud Risk Terhadap Deteksi Potensi Kecurangan Oleh Auditor}

Fraud risk dalam penelitian ini adalah bagian-bagian dari segitiga kecurangan yang diketahui sebagai pemicu terjadinya fraud. Fraud Risk dalam penelitian ini diukur melalui tiga indicator yaitu: kesempatan, tekanan dan rasionalisasi. Berdasarkan hasil penelitian diketahui bahwa fraud risk memiliki pengaruh positif terhadap deteksi potensi kecurangan. Hal ini berarti bahwa penerapan fraud risk memiliki pengaruh searah terhadap deteksi potensi kecurangan. Semakin sering dilakukan analisis fraud risk akan memberikan dampak pada meningkatnya deteksi potensi kecurangan oleh auditor. Sementara itu, berdasarkan uji parsial diketahui bahwa fraud risk memiliki pengaruh yang signifikan terhadap deteksi potensi kecurangan. Hal ini berarti bahwa fraud risk merupakan faktor penentu baik dan tidaknya deteksi potensi kecurangan. Hasil penelitian ini menunjukkan bahwa auditor BPKP Provinsi Sulawesi Selatan memiliki fraud risk yang baik, mulai dari kesempatan berupa sistem internal control yang kuat, tekanan berupa pembarian gaji yang mencukupi dan rasionalisasi berupa etika dan perilaku auditor yang baik. Hal - hal tersebut menjadi penyabab fraud risk menjadi factor penentu baik dan tidaknya deteksi potensi kecurangan. Hasil penelitian ini sejalan dengan hasil penelitian sebelumnya dari Hasil penelitian Aghghaleh et. al. (2014) dan Kiswanto dan Maulana (2019), yang menemukan bahwa fraud risk memiliki berpengaruh signifikan terhadap kemampuan auditor mendeteksi potensi kecurangan.

\section{KESIMPULAN}

Berdasarkan hasil penelitian dan pembahasan pada bab sebelumnya maka simpulan penelitian ini bahwa Brainstorming berpengaruh positif dan signifikan terhadap deteksi potensi kecurangan pada BPKP Provinsi Sulawesi Selatan. Hal ini berarti bahwa brainstorming adalah faktor pendukung dan faktor penentu baik dan tidaknya deteksi potensi kecurangan oleh auditor di BPKP Provinsi Sulawesi Selatan. Fraud risk berpengaruh positif dan signifikan terhadap deteksi potensi kecurangan pada Perwakilan BPKP Provinsi Sulawesi Selatan. Hal ini berarti bahwa fraud risk adalah faktor pendukung dan faktor penentu baik dan tidaknya deteksi potensi kecurangan oleh auditor di BPKP Provinsi Sulawesi Selatan.

\section{DAFTAR PUSTAKA}

Aghghaleh, S. F., \& . Z. M. M. (2014). Fraud Risk Factors of Fraud Triangle and the Likelihood of Fraud Occurrence: Evidence from Malaysia. Information Management and Business Review. https://doi.org/10.22610/imbr.v6i1.1095

Alfaruqi, I., \& Kristianti, I. (2019). Analisis Potensi Kecurangan Dalam Pengelolaan Keuangan Desa (Studi: Desa Kesongo, Kecamatan Tuntang, Kabupaten Semarang, Jawa Tengah). Jurnal Akuntansi Maranatha, 11(2), 199-210. 
https://doi.org/10.28932/jam.v11i2.1915

Alkotdriyah, P. P. (2020). Interpersonal Skill-Based Audit Team Brainstorming: Solution For Fraud Detection. 10(3), 458-474. https://doi.org/10.22219/jrak.v10i3.13017

Amran, A., Susanto, E., Kalsum, U., Fitrianti, F., \& Muslim, M. (2021). The Effect of Company Complexity and Company Size Against Audit Fees. Point of View Research Accounting and Auditing, 2(1), 59-65.

Association of Certified Fraud Examiners. (2012). Report To The National On Occupational Fraud and Abuse, Global Fraud Study 2012. ACFE Report, 20, 7587. https://www.acfe.com/uploadedFiles/ACFE_Website/Content/rttn/2012-reportto-nations.pdf

Berger, C., Calabrese, R., Ellul, J., Adorno, T., Horkheimer, M., Barthes, R., Ong, W., Luhmann, N., \& Castells, M. (2018). Communication theory.

Boynton, W. C., Johnson, R. N., \& Kell, W. G. (2003). Modern auditing jilid I (Edisi 7). Alih Bahasa Oleh Rajoe, PA, Gania, G. \& Budi, IS Jakarta: Penerbit Erlangga.

Brazel, J. F., Carpenter, T. D., \& Jenkins, J. G. (2010). Auditors' use of brainstorming in the consideration of fraud: Reports from the field. Accounting Review, 85(4), 1273-1301. https://doi.org/10.2308/accr.2010.85.4.1273

Brown, J. O. (2015). Conducting Effective Fraud Brainstorming Sessions: Best Practice Tips and Available Resources for Your Audit Teams.

Butar, S. G. A. (2017). Penerapan Skeptisme Profesional Auditor Internal Pemerintah dalam Mendeteksi Kecurangan (Studi Kasus pada Auditor Perwakilan BPKP Provinsi Jawa Tengah ). Jurnal Ekonomi Dan Bisnis, 20(1), 169-189.

Carpenter, T. D. (2007). Audit team brainstorming, fraud risk identification, and fraud risk assessment: Implications of SAS No. 99. The Accounting Review, 82(5), 1119-1140.

Chen, W., Khalifa, A. S., Morgan, K. L., \& Trotman, K. T. (2018). The effect of brainstorming guidelines on individual auditors' identification of potential frauds. Australian Journal of Management, 43(2), 225-240. https://doi.org/10.1177/0312896217728560

Dewi, N. W. P., \& Ramantha, I. W. (2016). Profesionalisme Sebagai Pemoderasi Pengaruh Kemampuan Investigatif pada Pembuktian Kecurangan oleh Auditor. Jurnal Akuntansi Universitas Udayana, 15(2), 1029-1055.

Hasbi, A. S. E. (2019). Pengaruh Audit Forensik, Audit Investigatif, dan Professional Judgment terhadap Pengungkapan Fraud dengan Kecerdasan Spiritual sebagai Variabel Moderating (Studi Perwakilan BPKP Provinsi Sulawesi Selatan). Universitas Islam Negeri Alauddin Makassar.

Hoffman, V. B., \& Zimbelman, M. F. (2009). Do strategic reasoning and brainstorming help auditors change their standard audit procedures in response to fraud risk? The Accounting Review, 84(3), 811-837.

Hunton, J. E., \& Gold, A. (2010). A field experiment comparing the outcomes of three fraud brainstorming procedures: Nominal group, round robin, and open discussion (retracted). The Accounting Review, 85(3), 911-935.

IAPI. (2012). Exposure draft SPA 240 (Issue 1).

IAPI. (2013). SA 200.pdf.

Intergrity Indonesia. (2017). Mengukur Resiko Fraud Perusahaan - Integrity Indonesia. https://www.integrity-indonesia.com/id/blog/2017/09/14/mengukur-resiko-fraud- 
perusahaan/

Jefri, R., \& Mediaty, M. (2014). Pendeteksian Kecurangan (Fraud) Laporan Keuangan. Jurnal Akuntansi STIE Muhammadiyah Palopo, 1(2).

Kala'tiku, T. A. R., Arifuddin, \& Syamsuddin. (2018). Brainstorming sebagai pemoderasi pengaruh pengalaman, pelatihan, skeptisisme profesional dan integritas terhadap kemampuan mendeteksi kecurangan. Jurnal Analisis, 7(1), 81-90. https://doi.org/2303-100X

KBBI. (2012). Arti Kata Curang Kamus Besar Bahasa Indonesia. Kbbi Daring. http://kbbi.web.id/rasial

Kiswanto, \& Maulana, P. A. (2019). Pengalaman Memoderasi Penilaian Resiko Kecurangan, Skeptisisme, Beban Kerja pada Kemampuan Mendeteksi Kecurangan. Jurnal Ilmiah Akuntansi Dan Bisnis, 14(2), 183-195.

Kumaat, V. G. (2011). Internal Audit, Erlangga. Jakarta.

Lannai, D., \& Muslim, M. (2021). Causality of Fraud Detection. Jurnal Akuntansi, 25(1), 19-33.

Mardiyati, S. (2001). Keefektifan teknik sumbang saran dan kerja individual dalam pelatihan berpikir divergen untuk meningkatkan kreativitas. [Yogyakarta]: Universitas Gadjah Mada.

Minaryanti, A. A., \& Ridwan, M. (2015). Tanggung Jawab Pendeteksian Kecurangan sebagai Pencegahan Kegagalan Audit (Studi pada Kantor Akuntan Publik di Jakarta). TRIKONOMIKA, 14(1), 57-65.

Mohd-Nassir, M.-D., Mohd-Sanusi, Z., \& Ghani, E. K. (2015). Brainstorming and auditor education background on internal control: Assessing fraud opportunity. International Conference on Accounting Studies (ICAS) 2015, August, 449-455.

Mohd-Nassir, M.-D., Mohd-Sanusi, Z., \& Ghani, E. K. (2016). Effect of brainstorming and expertise on fraud risk assessment. International Journal of Economics and Financial Issues, 6(4), 62-67.

Muslim, M., Ahmad, H., \& Rahim, S. (2019). The effect of emotional, spiritual and intellectual intelligence on auditor professionalism at the inspectorate of South Sulawesi Province. The Indonesian Accounting Review, 9(1), 73-84.

Nguyen, K. (2010). Financial statement fraud: Motives, methods, cases and detection. Universal-Publishers.

Osborn, A. F. (1953). Applied imagination: principles and procedures of creative problem solving. In Charles Scribeners Sons, New York (Vol. 26). OCLC.

Oxfordlearnersdictionaries.com. (2005). credibility noun - Definition, pictures, pronunciation and usage notes | Oxford Advanced Learner's Dictionary at OxfordLearnersDictionaries.com. Oxford Learners Dictionary. https://www.oxfordlearnersdictionaries.com/definition/english/fraud?q=fraud

Prasetyo, A. B. (2017). Dampak Kelompok Dan Ketergantungan Bantuan Pengambilan Keputusan Pada Penilaian Risiko Kecurangan. Jurnal Analisa Akuntansi Dan Perpajakan, 1(1), 1-18. https://doi.org/10.25139/jaap.v1i1.107

Priantara, D. (2013). Fraud auditing \& investigation. Jakarta: Mitra Wacana Media.

Rahim, S., Muslim, M., \& Amin, A. (2019). Red Flag And Auditor Experience Toward Criminal Detection Trough Profesional Skepticism. Jurnal Akuntansi, 23(1), 4762.

Rahim, S., Ahmad, H., Nurwakia, N., Nurfadila, N., \& Muslim, M. (2020). The Influence of Audit Staff Quality and Client Type on Audit Evidence Collection 
with Communication Type as Moderation. Journal of Accounting and Strategic Finance, 3(1), 103-117.

Ratmono, D. (2017). Dapatkah Teori Fraud Triangle Menjelaskan Kecurangan dalam Laporan Keuangan? Jurnal Akuntansi Dan Auditing, 14(2).

Redmond, M. V. (2015). Uncertainty reduction theory.

Salem, M. S. M. (2012). An overview of research on auditor's responsibility to detect fraud on financial statements. Journal of Global Business Management, 8(2), 218.

Shleifer, A., \& Vishny, R. W. (1993). Corruption. The Quarterly Journal of Economics, 108(3), 599-617.

Simatupang, M. (2019). Pengenalan Risiko Kecurangan - Kemenkeu Learning Center. https://klc.kemenkeu.go.id/pusku-pengenalan-risiko-kecurangan/

Suryanto, R., Indriyani, Y., \& Sofyani, H. (2017). Determinan Kemampuan Auditor dalam Mendeteksi Kecurangan. Muhammadiyah University Yogyakarta.

Suryoratri, G. E. (2012). Pengaruh Pertukaran Pendapat Dan Faktor Risiko Kecurangan Terhadap Pendeteksian Kecurangan. Universitas Negeri Jakarta.

Su'un, M., \& Hajering, M. (2020). Professional commitment and locus of control toward intensity in whistleblowing through ethical sensitivity. Jurnal Akuntansi, 24(1), 100-118.

Trotman, K. T., Bauer, T. D., \& Humphreys, K. A. (2015). Group judgment and decision making in auditing: Past and future research. Accounting, Organizations and Society, 47, 56-72.

Tuanakotta, T. M. (2013). Audit Berbasis ISA (International Standards on Auditing). Jakarta: Salemba Empat.

Tuanakotta, T. M. (2015). Audit kontemporer. Jakarta: Salemba Empat.

Widarti, W. (2015). Pengaruh Fraud Triangle Terhadap Deteksi Kecurangan Laporan Keuangan Pada Perusahaan Manufaktur Yang Terdaftar Di Bursa Efekindonesia (Bei). Jurnal Manajemen Dan Bisnis Sriwijaya, 13(2), 229-244. https://doi.org/10.29259/jmbs.v13i2.3351 